\title{
Komunitas Hijabers Gresik: Produksi dan Konsumsi Informasi Fashion Hijab
}

\section{Gresik Hijabers Community: Production and Consumption of Hijab}

\section{Fashion Information}

\author{
Ariatul Qibtiyah \\ Departmen Ilmu Informasi dan Perpustakaan \\ Fakultas Ilmu Sosial dan Ilmu Politik, Universitas Airlangga \\ ariatul.qibtiyah-2015@fisip.unair.ac.id
}

\begin{abstract}
With the increasingly developed information and communication technology, also the increasingly diverse social media that exist today makes the production and consumption of information activities can be carried out by the entire community easily. One of the information that is currently a trend among the people, especially women, is information related to hijab fashion, which is currently being produced by influencers and hijab celebrities and is also widely consumed by the public through social media. Therefore it is a phenomenon that through social media today users do not only act as information consumers but they can also act as active producers of information on their personal accounts. The research was conducted on members of the Hijabers Gresik community by getting 54 respondents. The purpose of this study is to find out how the production activities and consumption of hijab fashion information are carried out by members of the Hijabers Gresik community, and at the same time want to know the relationship between production activities and consumption of hijab fashion information that has been carried out. In addition, this study also aims to find out the reasons why respondents produce and consume hijab fashion information on their social media accounts. To get the results of this study, researchers conducted structured interviews by distributing questionnaires to the respondents. And the result is that $100 \%$ of respondents conduct production activities and consumption of hijab fashion information, with as many as $31 \%$ of respondents producing hijab fashion information for work demands in the form of endorse photos, paid promoting and also Muslim wedding dress models of a Wedding Organizer, and before producing 33\% respondents need hijab fashion information about hijab fashion trends that are up to date (including hijab styles, Muslim fashion outfits). The production and consumption activities of hijab fashion information are carried out by utilizing existing social media, of which as many as $48 \%$ of respondents use Instagram to access and create hijab fashion information simultaneously. So that the convenience offered by social media which is a representation of web 2.0 makes the production and consumption activities of hijab fashion information very easy to do and the activities of producing hijab fashion information can be used as a profitable business field by bringing in indirect feedback.
\end{abstract}

Keywords : Hijab fashion information production; Hijab fashion information consumption; Interrelation of production and consumption of hijab fashion information; Prosumption on social media

\section{Abstrak}

Dengan semakin berkembang nya teknologi informasi dan komunikasi, juga semakin beragam nya media sosial yang ada saat ini menjadikan aktivitas produksi dan konsumsi informasi dapat dilakukan oleh seluruh kalangan masyarakat dengan mudah. Salah satu informasi yang saat ini sedang trend dikalangan masyarakat terutama kalangan perempuan adalah informasi terkait fashion hijab, yang mana informasi fashion hijab tersebut saat ini sedang banyak diproduksi oleh para kalangan influencer maupun selebriti berhijab dan juga banyak dikonsumsi oleh masyarakat melalui media sosial. Oleh sebab itu hal tersebut menjadi suatu fenomena bahwa melalui media sosial saat ini peengguna tidak hanya berperan sebagai konsumer informasi saja melainkan mereka juga dapat berperan sebagai produser informasi yang aktif pada akun-akun pribadi milik mereka. Penelitian ini dilakukan pada anggota komunitas Hiabers Gresik dengan mendapatakan responden sebanyak 54 responden. Tujuan dari penelitian ini adalah ingin mengetahui bagaimana aktivitas produksi dan konsumi informasi fashion hijab yang dilakukan oleh anggota komunitas Hijabers Gresik, sekaligus ingin mengetahui keterkaitan antara aktivitas produksi dan konsumsi informasi fashion hijab yang telah dilakukan. Selain itu penelitian ini juga bertujuan untuk mengetahui alasan mengapa para reponden memproduksi dan mengkonsumsi informasi fashion hijab tersebut pada akun media sosial mereka. Untuk mendapatkan hasil dari penelitian ini, peneliti melakukan wawancara terstruktur dengan menyebarkan kuesioner kepada para responden. Dan hasil nya adalah bahwa 100\% responden melakukan aktivitas produksi dan konsumsi informasi fashion hijab, dengan sebanyak $31 \%$ responden memproduksi informasi fashion hijab untuk tuntutan pekerjaan berupa foto endorse, paid promote dan juga model gaun 
pengantin muslimah sebuah Wedding Organizer, dan sebelum memproduksi 33\% responden membutuhkan informasi fashion hijab seputar trend fashion hijab yang sedang up to date (meliputi gaya hijab, outfit busana muslim). Aktivitas produksi dan konsumsi informasi fashion hijab ini dilakukan dengan memanfaatkan media sosial yang ada, yang mana sebanyak $48 \%$ responden menggunakan instagram untuk mengakses dan menciptakan informasi fashion hijab secara bersamaan. Sehingga dengan kemudahan yang ditawarkan oleh media sosial yang merupakan representasi dari web 2.0 menjadikan aktivitas produksi dan konsumsi informasi fashion hijab ini sangat mudah dilakukan serta aktivitas produksi informasi fashion hijab dapat dijadikan sebagai ladang bisnis yang menguntungkan dengan mendatangkan feedback secara tidak langsung.

Kata Kunci : Produksi informasi fashion hijab; Konsumsi informasi fashion hijab; Keterkaitan produksi dan konsumsi informasi fashion hijab; Prosumption pada media sosial.

\section{Pendahuluan}

Pada saat ini keberadaan internet khusus nya media social banyak digunakan oleh kalangan masyarakat untuk berbagi maupun mendapatkan berbagai macam informasi. Salah satu nya adalah pada komunitas Hijabers Gresik, dimana saat ini para anggota atau member dari komunitas Hijabers Gresik sering memanfaatkan internet untuk melakukan aktivitas produksi dan konsumsi informasi terkait fashion hijab pada akun media social yang mereka miliki. Tujuan dari aktivitas produksi dan konsumsi informasi yang dilakukan oleh komunitas Hijabers Gresik tersebut adalah salah satu nya untuk kepentingan ekonomi. Misalnya produksi informasi terkait fashion hijab yang dilakukan oleh beberapa anggota komunitas Hijabers Gresik ini berisi tentang paid promote atau endorse dari berbagai online shop yang menjual berbagai macam perlengkapan yang berkaitan dengan fashion hijab seperti hijab, busana muslim, dan lain sebagainya. Sehingga mereka (anggota komunitas Hijabers Gresik) dituntut dan diwajibkan untuk mengupload mengenai informasi terkait barang - barang endorse tersebut seperti hijab, busana muslim dan lain sebagainya pada akun media social pribadi mereka yang tentunya sesuai dengan perjanjian dengan si penjual online shop tersebut.

Aktivitas produksi informasi terkait fashion hijab yang dilakukan oleh komunitas Hijabers Gresik pada akun media social nya biasanya berupa informasi - informasi baik berupa foto maupun video terkait model fashion hijab terkini yang sedang trend dikalangan masyarakat, karena informasi terkait fashion hijab pada saat ini tengah di gandrungi oleh berbagai macam kalangan masyarakat. Hal tersebut bertujuan untuk menambah pengetahuan dan juga wawasan mengenai fashion hijab, serta dapat dijadikan sebagai referensi untuk bisa memproduksi informasi fashion hijab yang lebih menarik.

Keberadaan internet dan juga kecanggihan teknologi yang ada di tengah kehidupan masyarakat modern pada saat ini tentu sangat memudahkan komunitas Hijabers Gresik dalam melakukan berbagai macam aktivitas kesehariannya. Salah satu dampak dari keberadaan internet dan juga kecanggihan teknologi yang semula web 1.0 menjadi web 2.0 menjadikan semakin beragamnya platform media digital yang digunakan masyarakat untuk berkomunikasi dan bersosialisasi dengan masyarakat lain, Nasrullah (dalam Husna et al 2018:90) membagi platform media digital menjadi 11 jenis media digital, dari ke 11 jenis platform media digital tersebut yang paling sering digunakan masyarakat saat ini untuk berkomunikasi, mencari sekaligus menciptakan 
informasi adalah melalui media social. Karena media social dapat diakses oleh semua kalangan masyarakat tanpa terkecuali dan mereka dapat mengaksesnya kapanpun dan dimanapun mereka menginginkannya.

Munculnya berbagai macam media sosial yang ada pada saat ini dimanfaatkan oleh beberapa orang untuk dapat terlibat dalam proses produksi dan konsumsi informasi. Salah satu jenis informasi yang tengah digandrungi masyarakat khususnya para kaum perempuan saat ini adalah informasi terkait dengan fashion hijab. Hal tersebut dikarenakan jumlah perempuan yang menggunakan hijab dari tahun ke tahun selalu mengalami kenaikan, sehingga segala macam informasi yang berkaitan dengan fashion hijab selalu ramai di konsumsi maupun di produksi oleh masyarakat. Kegiatan produksi dan konsumsi informasi tidak hanya terjadi dalam bidang fashion hijab dan kecantikan saja, melainkan juga dapat terjadi di berbagai bidang salah satunya adalah bidang seni.

Adanya para selebriti dan juga vlogger berhijab di media social menjadikan para kaum perempuan berhijab lebih mudah untuk mendapatkan informasi terkait dengan fashion hijab. Menurut Uly Darojah president komunitas hijabers Gresik periode ke 4 jumlah anggota komunitas hijabers yang tergabung dalam grup WhatsApp ada 115 orang yang mana para anggota nya tidak hanya berasal dari Kota Gresik saja melainkan dari kota Gerbang Kertasusila (Gresik, Bangkalan, Mojokerto, Surabaya, dan Lamongan). Biasanya para anggota komunitas Hijabers Gresik tersebut memproduksi berbagai macam informasi terkait dengan fashion hijab seperti tutorial hijab pada akun media social masing - masing, mereka juga sharing mengenai fashion - fashion hijab yang sedang menjadi trend di kalangan masyarakat. Selain itu biasanya para anggota juga mengikuti event - event fashion show yang kemudian fashion yang mereka gunakan dalam event tersebut akan mereka unggah pada akun media social nya.

Berdasarkan macam - macam fenomena yang melibatkan media social sebagai sarana untuk memproduksi dan mengkonsumsi informasi terkait dengan fashion hijab, maka dalam penelitian ini peneliti tertarik dan ingin mengetahui proses aktivitas produksi dan konsumsi informasi mengenai fashion hijab yang dilakukan oleh komunitas hijabers Gresik. Dalam penelitian ini peneliti juga ingin menggambarkan bagaimana alur proses para anggota komunitas hijabers Gresik dari mencari dan mengakses berbagai macam informasi yang dibutuhkan terkait dengan fashion hijab sampai mereka juga dapat memproduksi informasi terkait dengan fashion hijab dan kemudian membagikan nya pada akun media social mereka masing - masing.

\section{Metode Penelitian}

Penelitian ini menggunakan teori dari Ritzer tentang presumption. Metode penelitian yang digunakan dalam penelitian ini adalah kuantitatif deskriptif. Penelitian ini dilakukan di kota Gresik, dengan anggota komunitas Hijabers Gresik yang masih aktif sebagai populasi nya. Dalam penelitian ini peneliti menggunakan teknik purposive sampling yang mana teknik purposive sampling menurut Sugiyono (2012:126) adalah teknik penentuan sampel dengan pertimbangan tertentu. Sehingga, dalam pengambilan sampel penelitian mengenai "Produksi dan Konsumsi 
Informasi Fashion Hijab pada Komunitas Hijabers Gresik” diperoleh 54 responden yang memenuhi karakteristik sebagai berikut :

1. Anggota komunitas Hijabers Gresik yang masih aktif dalam komunitas Hijabers Gresik

2. Pernah mengunggah informasi terkait dengan fashion hijab seperti foto fashion hijab, tutorial hijab, fotografi, modelling maupun fashion show pada akun media social seperti instagram, youtube, facebook, dll. dalam jangka waktu minimal satu bulan sekali.

3. Pernah mengikuti event modelling maupun fashion show muslimah sehingga mereka lebih mengerti akan gaya fashion hijab.

4. Anggota komunitas Hijabers Gresik yang mengakses informasi terkait fashion hijab dalam jangka waktu minimal seminggu 3 kali.

5. Pernah menonton event fashion show maupun parade busana muslim lain nya.

\section{Hasil dan Pembahasan}

\section{Aktivitas Produksi Informasi Fashion Hijab}

Dalam penelitian ini diperoleh data bahwa sebesar $81,5 \%$ responden memproduksi informasi fashion hijab sebanyak 1-3 kali dalam kurun waktu satu bulan. Data yang diperoleh tersebut hampir sama dengan hasil data dari penelitian yang dilakukan oleh Rachmawati (2018) terkait produksi dan konsumsi informasi kecantikan pada mahasiswa tata rias Universitas Negeri Surabaya bahwasanya mayoritas mahasiswa tata rias sebesar 41,4\% menciptakan informasi kecantikan sebanyak 1-2 kali dalam kurun waktu satu bulan.

Negri, 1989 (dalam Ritzer et al 2012:382) mengatakan bahwa fakta pada saat ini adalah banyak produksi yang telah berpidah ke luar tembok pabrik dan ke masyarakat secara keseluruhan, sehingga masyarakat mampu menciptakan pabrik sosial sendiri tanpa adanya pabrik secara nyata. Sehingga hampir secara keseluruhan responden pernah melakuakn aktivitas produksi informasi pada media sosial nya. Sebesar $44,4 \%$ responden biasanya memproduksi informasi fashion hijab berupa Trend fashion hijab (model hijab), dan sebesar 53,7\% responden memilih memproduksi informasi fashion hijab berupa Trend fashion hijab (model hijab) karena menurut mereka informasi fashion hijab tersebut sedang trend dan up to date pada saat ini.

Dalam penelitian ini seluruh responden $\mathbf{1 0 0 \%}$ memilih menggunakan media elektronik seperti media sosial dan internet untuk mendukung aktivitas produksi informasi seperti untuk mengunggah konten informasi fashion hijab yang mereka ciptakan, Jenis media sosial yang paling banyak digunakan oleh responden untuk mengunggah konten informasi fashion hijab adalah Instagram, yaitu sebesar 90,7\%. Berbeda hal nya dengan penelitian yang dilakukan oleh Sarah (2015) yang mengungkapkan bahwa dalam proses produksi Trending Topic media sosial memiliki peran yang sangat besar, media sosial dalam penelitian ini digunakan untuk mencari topik dan video yang menarik yang sedang viral dikalangan masyarakat.

Media sosial dapat memberikan peluang pekerjaan bagi siapa saja yang tertarik dan ikut serta berkontribusi dengan memberikan feedback terbuka serta membagikan informasi dalam waktu yang cepat dan tak terbatas (Kaplan et al 2010). Sebesar 79,6 \% responden menciptakan 
Palimpsest: Journal of Information and Library Science Vol. 11, Issue 2, 2020, page 100-105

informasi fashion hijab dengan mengupload foto pada akun media sosial milik pribadi.

Penciptaan informasi fashion hijab yang dilakukan oleh anggota komunitas Hijabers Gresik ternyata memiliki alasan dan tujuan yang sama yaitu karena tuntutan pekerjaan, yaitu sebesar $57,4 \%$ responden menciptakan informasi fashion hijab dengan alasan karena tuntutan pekerjaan dan sebesar $61,1 \%$ responden menciptakan informasi fashion hijab dengan tujuan untuk pekerjaan. Data yang diperoleh tersebut sesuai dengan penelitian yang dilakukan oleh Sugihartati (2017:13) bahwasanya penggemar The Mortal Instruments yang kritis dan kreatif dapat dapat dijadikan sebagai cara untuk mereka mempromosikan teks budaya favorit mereka pada penggemar lain dengan memberikan kebebasan untuk memproduksi, mereproduksi serta mengedarkan produk teks budaya mereka. Sehingga secara tidak langsung mereka dapat dikatakan sebagai para buruh bebas yang akan mendapatkan lebih banyak keuntungan dengan kekuatan kapitalis yang mereka lakukan.

\section{Aktivitas Konsumsi Informasi Fashion Hijab}

Dalam aktivitas konsumsi informasi fashion hijab diperoleh data bahwa Sebesar 38,9\% responden mengakses informasi fashion hijab sebanyak 7-9 kali dalam kurun waktu 1 minggu. Hasil tersebut berbeda dengan penelitian yang dilakukan oleh Rachmawati (2018) terkait produksi dan konsumsi informasi kecantikan pada mahasiswa tata rias Universitas Negeri Surabaya bahwa mayoritas mahasiswa tata rias sebesar 28,3\% hanya mengkonsumsi informasi kecantikan sebanyak 1-2 kali saja dalam kurun waktu 1 minggu.

Jika dilihat dari perspektif ilmu ekonomi klasik konsumsi menurut Featherstone (2001:31) adalah semua objek dari produksi dengan individu yang memaksimalkan kepuasan mereka melalui pembelian, sehingga sebesar $50 \%$ responden mengakses informasi fashion hijab terkait tutorial fashion hijab (hijab, mix and match outfit busana muslim), dan sebesar $42,6 \%$ responden memilih mengikuti trend mix and match hijab dengan outfit busana muslim dalam mengakses informasi fashion hijab. Informasi-informasi fashion hijab tersebut adalah informasi fashion hijab yang biasanya diakses oleh anggota komunitas Hijabers Gresik untuk memenuhi kebutuhan informasi mereka terkait fashion hijab. Sebesar 33,3\% responden memilih mengakses informasi fashion hijab tersebut karena sedang digemari oleh masyarakat sehingga mereka penasaran untuk mengakses nya.

Tingkat konsumsi seseorang pada saat ini sangat dipengaruhi oleh adanya media massa (baik cetak maupun eletronik), Donohew, Palmgreen dan Rayburn (1987) menganalisis terdapat beberapa faktor yang mempengaruhi tingkat konsumsi seseorang terhadap media massa. Dalam hal ini media yang paling banyak digunakan oleh responden untuk mengakses informasi fashion hijab adalah media elektronik, terbukti bahwa sebesar 90,7\% responden memilih menggunakan media elektronik (seperti media sosial dan lain-lain) untuk mengakses informasi fashion hijab yang dibutuhkan dan diinginkan.

Sebesar 38,9\% responden sering membutuhkan informasi fashion hijab terkait trend fashion hijab (model hijab, model busana muslim) yang sedang up to date dan hanya sebesar 1,9\% responden yang sering membutuhkan informasi fashion hijab terkait review mengenai berbagai 
jenis kain hijab. Dengan demikian media elektronik (seperti media sosial dan lain-lain) sangat membantu dan memudahkan responden dalam mengakses informasi-informasi fashion hijab terbaru yang mereka butuhkan, karena ke-update-an informasi fashion hijab yang mereka miliki akan sangat berguna untuk menunjang karir pekerjaan dan juga fashion style berhijab diri mereka sendiri.

Aktivitas konsumsi informasi fashion hijab yang dilakukan oleh responden selain hanya sekedar kebutuhan saja juga memiliki tujuan masing-masing yang ingin dicapai dan diwujudkan. Dalam penelitian ini sebesar $46,3 \%$ responden mengakses informasi fashion hijab dengan tujuan agar informasi fashion hijab yang dimiliki selalu up to date, dan sebesar $7,4 \%$ responden mengakses informasi fashion hijab dengan tujuan untuk menunjang karir dan pekerjaan. Hasil tersebut sama hal nya dengan hasil penelitian yang dilakukan oleh Rachmawati (2018) terkait produksi dan konsumsi informasi kecantikan pada mahasiswa tata rias Universitas Negeri Surabaya yang menunjukkan bahwa sebesar 43,3\% mahasiswa mengkonsumsi informasi kecantikan untuk menunjang karir dan akademiknya, sedangkan sebesar 37,7\% mahasiswa mengkonsumsi informasi kecantikan untuk menambah pengetahuan mengenai kecantikan.

Young (2001:13) mengungkapkan bahwa konsumsi pada media social merupakan keaktifan pengguna melakukan suatu aktivitas memilih media berdasarkan keinginannya dan mereka menggunakan media tersebut untuk memenuhi kebutuhannya. Sebesar 66,7\% responden menggunakan media sosial jenis instagram untuk melakukan aktivitas konsumsi informasi fashion hijab. Sedangkan jenis media sosial yang paling sedikit diminati oleh responden dalam melakukan aktivitas konsumsi informasi fashion hijab adalah WhatsApp dengan prosentase sebesar 3,7\% saja.

Dengan menggunakan media sosial aktivitas konsumsi informasi fashion hijab yang dilakukan oleh responden dapat berjalan dengan baik sesuai dengan perkembangan zaman yang ada. Ritzer (2014:14) berpendapat bahwa pada saat ini kegiatan konsumi jauh lebih mudah dilakukan dan tidak perlu memakan banyak waktu karena perkembangan sarana komunikasi yang jauh lebih baru bila dibandingkan dengan abad ke-19 lalu yang membutuhkan perjalanan panjang untuk menuju sarana komunikasi. Sebesar 64,8\% responden memilih menggunakan media sosial dalam melakukan aktivitas konsumsi informasi karena mudah diakses, sedangkan sebesar 5,6\% memilih menggunakan media sosial karena mengikuti trend.

Ritzer (2015:5) berpendapat bahwa konsumsi informasi melalui dunia maya adalah suatu kegiatan dimana pengguna mengunduh dan menggunakan sutau informasi. Dalam penelitian ini responden menggunakan berbagai macam cara untuk dapat mengakses sekaligus mendapatkan informasi fashion hijab yang mereka inginkan, pernyataan tersebut didukung data yang diperoleh peneliti yaitu sebesar 59,3\% respoden menggunakan cara dengan selalu mengikuti media sosial para selebgram, youtubers, maupun selebriti berhijab untuk mendapatkan informasi fashion hijab yang up to date dan sebesar $11,1 \%$ responden mendapatkan infomasi fashion hijab dengan cara selalu mengikuti perkembangan hijab di lingkungan sekitar. 
Kombinasi antara aktivitas produksi dan aktivitas konsumsi biasanya disebut dengan istilah Prosumption. Aktivitas produksi dan konsumsi informasi merupakan dua elemen yang tidak dapat dipisahkan dan mempunyai keterkaitan satu sama lain. Pernyataan tersebut sesuai dengan apa yang telah dikatakan oleh Ritzer et al (2012:381) dimana produksi selalu melibatkan konsumsi dan begitu juga sebaliknya. Oleh sebab itu apabila terdapat aktivitas produksi maka secara otomatis juga terdapat aktivitas konsumsi.

Vivakaran dan Neelamalar (2018:5) mengungkapkan bahwa platform sosial online telah menjadikan kegiatan pengumpulan informasi dan berbagi pengetahuan menjadi proses yang mudah dan mengubah para konsumen pasif menjadi generator konten aktif. Jadi dengan semakin canggihnya perkembangan Teknologi Informasi dan Komunikasi pada saat ini menjadikan para responden yang dulu nya pasif dalam hal mengakses informasi kini mereka menjadi aktif dalam mengakses informasi fashion hijab sesuai dengan kebutuhannya. Pernyataan tersebut sesuai dengan data yang diperoleh peneliti bahwa mayoritas responden sebesar 55,6\% mengakses informasi fashion hijab sebanyak 3-4 kali sebelum mereka menciptakan informasi fashion hijab dengan memanfaatkan kecanggihan teknologi yang ada dan menggunakan media sosial yang mereka miliki.

Davis dalam Bashir dan Madhavaiah (2014:154) menyatakan bahwa terdapat model teoritis untuk menjelaskan beberapa faktor yang mempengaruhi perilaku penerimaan seseorang terhadap sistem informasi, salah satu faktor tersebut adalah Perceived usefulness (pengguna merasa percaya bahwa dengan menggunakan teknologi tersebut bisa meningkatkan produktivitas dan keefektifan kinerja) (Destiana et al., 2013:130). Peryataan tersebut selaras dengan data yang diperoleh peneliti bahwa sebesar $88,9 \%$ responden memilih menggunakan instagram untuk mendukung aktivitas produksi dan konsumi informasi fashion hijab yang mereka lakukan.

Sedangkan sebesar 51,9\% responden memilih menggunakan media sosial instagram untuk mendukung aktivitas produksi dan konsumsi informasi fashion hijab mereka dengan alasan karena menurut mereka instagram lebih mudah diakses. Data tersebut sesuai dengan salah satu faktor yang mempengaruhi perilaku penerimaan seseorang terhadap sistem informasi yaitu Perceived ease of use (pengguna merasa percaya bahwa suatu teknologi mudah untuk digunakan) (Destiana et al., 2013:130).

Selain itu keuntungan dari kecanggihan teknologi yang ada pada saat ini adalah bahwa aktivitas produksi dan konsumsi informasi fashion hijab yang dilakukan oleh anggota komunitas Hijabers Gresik dapat dilakukan dalam waktu bersamaan dan juga dengan menggunakan alat atau media yang sama. Shirky dalam Nightingale (2011:109) mengungkapkan bahwa pada suatu media apabila terdapat konsumer baru maka secara otomatis produser baru juga akan bergabung, karena aktivitas produksi dan konsumi informasi yang dilakukan menggunakan alat yang sama maka tidak dapat dipungkiri bahwa kedua aktivitas tersebut juga dilakukan dalam waktu yang sama pula. Hal tersebut sesuai dengan data yang diperoleh peneliti bahwa sebesar $61,1 \%$ responden dapat mengakses sekaligus menciptakan informasi fashion hijab secara bersamaan sebanyak 1-3 kali dalam kurun waktu 1 bulan. 
Sebesar 51,9\% responden biasanya mengkonsumsi sekaligus menciptakan konten informasi fashion hijab berupa foto outfit busana muslim yang sedang trend dikalangan masyarakat. Pernyataan tersebut sesuai dengan pendapat yang telah dikemukakan oleh Warner (2002) bahwasanya Hijabers merupakan agen dalam cetakan budaya pop islam, dimana mereka tidak hanya memiliki kekuatan sebagai konsumen saja melainkan mereka juga dapat memproduksi public atau informasi baru.

\section{Kesimpulan}

Jadi dapat disimpulkan bahwa rata-rata anggota komunitas Hijabers Gresik melakukan aktivitas produksi informasi fashion hijab pada akun media sosial milik pribadi, responden melakukan aktivitas produksi informasi fashion hijab sebanyak 1-3 kali dalam kurun waktu 1 bulan. Aktivitas produksi informasi fashion hijab yang dilakukan oleh responden bertujuan untuk memperoleh keuntungan secara financial dan juga sebagai ladang bisnis atau pekerjaan.

Pekerjaan tersebut salah satu nya adalah berupa foto endorse dan paid promote dari berbagai online shop yang menjual berbagai macam perlengkapan hijab dan busana muslim, setelah itu anggota komunitas Hijabers Gresik akan mendapatkan feedback atau bayaran dari client atau online shop yang bersangkutan. Selain foto endorse dan paid promote, pekerjaan lain yang biasa diperoleh anggota komunitas Hijabers Gresik adalah biasanya mereka dijadikan sebagai model gaun pengantin muslimah oleh sebuah wedding organizer, yang mana mereka dituntut untuk dapat memamerkan gaun pengantin muslimah yang mereka pakai dalam sebuah event atau pameran wedding, karena untuk saat ini gaun pengantin muslimah sedang trend dan banyak diminati oleh masyarakat untuk digunakan pada hari pernikahannya.

Untuk aktivitas konsumsi informasi fashion hijab yang dilakukan oleh anggota komunitas Hijabers Gresik ini lebih besar diperoleh dari akun-akun media sosial para influencer seperti selebgram dan youtuber berhijab yang mereka ikuti atau follow di akun media sosial pribadi. Mereka jarang atau hampir tidak pernah pergi ke perpustakaan untuk mencari koleksi yang berkaitan dengan fashion hijab.

Mayoritas responden lebih memilih menggunakan cara tersebut bila dibandingkan harus mencari informasi fashion hijab yang ada di perpustakaan, karena menurut mereka informasi fashion hijab yang terdapat di media sosial selalu megikuti perkembangan zaman, sangat mudah diakses serta selalu menampilkan informasi yang up to date dan fresh, berbanding terbalik dengan koleksi dan informasi fashion hijab yang terdapat di perpustakaan yang koleksi nya sangat sedikit dan jarang di up date sehingga responden malas berkunjung ke perpustakaan untuk kepentingan mencari informasi fashion hijab yang dibutuhkan.Tujuan responden melakukan aktivitas konsumsi informasi fashion hijab adalah agar informasi fashion hijab yang mereka miliki selalu up to date dan mengikuti perkembangan zaman yang ada.

Ternyata memang benar bahwa aktivitas produksi dan konsumsi informasi memiliki keterkaitan satu sama lain, hal tersebut dapat dibuktikan bahwa responden yang akan melakukan aktivitas produksi informasi fashion hijab selalu melakukan aktivitas konsumsi informasi fashion 
hijab terlebih dahulu untuk dijadikan sebagai referensi dalam menciptakan informasi fashion hijab yang baru dan tentunya lebih menarik.

Hampir secara keseluruhan responden pernah melakukan aktivitasproduksi dan konsumsi informasi fashion hijab secara bersamaan dalam keseharian mereka. Aktivitas produksi dan konsumsi fashion hijab tersebut dilakukan secara bersamaan karena tuntutan pekerjaan. Aktivitas konsumsi informasi fashion hijab yang dilakukan oleh responden selalu sesuai dengan aktivitas produksi informasi fashion hijab yang akan diciptakan.

\section{Daftar Pustaka}

Bashir, Irfan \& C. Madhavaiah. (2014). Determinants of young consumers' intention to use internet banking services in India. Journal of Vision 18(3) pp 153-163.

Baulch, Emma, Alila Pramiyanti. (2018). Hijabers onInstagram: Using Visual Social Media to Construct the Ideal Muslim Woman. School of Art and Social Sciences. Monash University. Malaysia. Published by : Journals.sagepub.com.

Destiana, Ika, Ali Salman \& Mohd. Helmi Abd. Rahim (2013) Penerimaan media sosial : kajian dalam kalangan pelajar university di Palembang. Malaysian Journal of Communication 29(2) pp 125-140.

Donohew, $\quad$ L., Palmgreen, P., \&Rayburn, J. D. (1987). Social and psychological origins of media use: A lifestyle analysis. Journal of Broadcasting and Electronic Media, Volume 31, 255-278.

Fitriani, Yuni. (2017). Analisis Pemanfaatan Berbagai Media Sosial Sebagai Sarana Penyebaran Informasi Bagi Masyarakat. Paradigma, Vol. 19, No. 2, September 2017 :17-32. (Di akses tanggal 26 Februari 2019).

Husna, Maruti Asmaul, Subagio dan Budi Irawanto. (2018). Beyond Prosumption : Praktik Prosumsi Penulis Konten dalam Platform News Aggregator Uc News. Jurnal Mayarakat Indonesia-LIPI, Vol. 44, No. 1 Juni 2018.ISSN : 0125-9989

Kaplan, Andreas M and Michael Haenlein. (2010). Users of the world, unite! The challenges and opportunities of Social Media.

Nakajima, Seio. (2011). Prosumption in Art. American Behaviour Scientist. P. 551. Tersedia di (http://sagepublications.com). Diakses pada 8 Maret 2019.

Nightingale, Virginia. (2011). The Handbook of Media Audience. [s.1]: Blackwell Publishing.

Rachmawati, Mardiyah. (2018). Produksi dan Konsumsi Informasi Kecantikan pada Mahasiswa Pendidikan Tata Rias Universitas Negeri Surabaya. Universitas Airlangga [skripsi].

Ritzer, George. (2010). Berfokus pada prosumer: Pada mengoreksi kesalahan dalam sejarah sosial teori. Dalam B. Blättel- Mink \& K. Hellmann (Eds.), Prosumer ditinjau kembali: Zur aktualität einer debatte ( pp. 61-79). Wiesbaden, Jerman: VS Verlag für Sozialwissenschaften. 
Palimpsest: Journal of Information and Library Science Vol. 11, Issue 2, 2020, page 105-105

Ritzer G and Jurgenson N. (2010). Production, consumption, prosumption: The nature of capitalism in the age of the digital 'prosumer'. Journal of Consumer Culture 10(1): 13-

36.

Ritzer, George, Paul Dean, \& Nathan Jurgenson. (2012). The coming of age of the prosumer. American Behavioral Scientist 56(4) pp 379-398.

Ritzer, George (2014) Prosumption: Evolution, revolution, or eternal return of the same? Journal of Consumer Culture 14(1): 3-24.

Ritzer, George (2015) Automating prosumption: The decline of the prosumer and the rise of the prosuming machines. Journal of Consumer Culture 15(3): 407-424.

Ritzer, George (2015) The New World of Prosumption: Evolution, return of same, or revolution. Sociological Forum 30(1) pp 1-17

Sarah, Maulida. (2015). Pemanfaatan Media Sosial dalam Proses Produksi Trending Topic di Metro Tv. Universitas Binus [thesis].

Sugihartati, Rahmah. (2017). Youth fans of global popular culture: Between prosumer and free digital labourer. Journal of Consumer Culture. $0(0)$ pp 1-

19.

Sugiyono. (2012). Metode Penelitian Kuantitatif Kualitatif dan R\&D. Bandung : Alfabeta.

Vivakaran, Mangala Vadivu, \& M. Neelamalar. (2018). Utilization of social media platforms for educational purposes among the faculty of higher education with special reference to Tamil Nadu. Higher Education for Future 5(1) pp 4-19.

Warner, M. (2002). Publics and Counterpublics. New York, NY: Zone Books.

Young, Sherman. (2001). What's the big idea? Production, consumption and internet regulatory discouse. Media International Australia incorporating Culture and Policy 101 pp 9-18. 